\title{
Bioavailability of dissolved and sediment-bound metals to a marine deposit-feeding polychaete
}

\author{
Wen-Xiong Wang ${ }^{1,2, *}$, Ian Stupakoff ${ }^{1}$, Nicholas S. Fisher ${ }^{1}$ \\ ${ }^{1}$ Marine Sciences Research Center, State University of New York, Stony Brook, New York 11794-5000, USA \\ ${ }^{2}$ Department of Biology, The Hong Kong University of Science and Technology, Clear Water Bay, Kowloon, Hong Kong
}

\begin{abstract}
Assimilation efficiencies (AEs) of trace elements ( $\mathrm{Ag}, \mathrm{Cd}, \mathrm{Co}, \mathrm{Se}$ and $\mathrm{Zn}$ ) in a marine deposit-feeding polychaete, Nereis succinea, from ingested sediments were measured using a pulsechase radiotracer feeding technique. Radiolabeled sediments were encapsulated and fed to the worms for $1 \mathrm{~h}$, after which the worms were allowed to depurate their ingested materials for $3 \mathrm{~d}$. The ranges of AEs were 12 to $36 \%$ for $\mathrm{Ag}, 5$ to $44 \%$ for Cd, 35 to $96 \%$ for Co, 29 to $60 \%$ for Se and 21 to $59 \%$ for $\mathrm{Zn}$. Trace metal assimilation was little affected by sediment source and sediment grain size. Metals (Ag, $\mathrm{Cd}, \mathrm{Co}$ and $\mathrm{Zn}$ ) associated with anoxic sediments were assimilated with a significantly lower efficiency than metals from oxic sediments. The $\mathrm{AE}$ of $\mathrm{Cd}$ decreased with the duration of sediment radiolabeling; AEs of $\mathrm{Ag}, \mathrm{Co}$, Se and $\mathrm{Zn}$ were weakly affected by sediment aging. Metal uptake in worms from the dissolved phase was proportional to metal concentration in the dissolved phase, although there was some evidence of $\mathrm{Cd}$ and $\mathrm{Zn}$ regulation in response to an increase in ambient concentrations. Uptake rate constants were highest for $\mathrm{Ag}$, followed by $\mathrm{Zn}>\mathrm{Co}>\mathrm{Cd}>$ Se. By incorporating metal influx from both the dissolved and particulate (sediment) phases, a bioenergetic-based kinetic model indicates that most (>98\%) of the $\mathrm{Cd}$, Co, Se and $\mathrm{Zn}$ in polychaetes arises from sediment ingestion due to the high ingestion rates of these animals and the low uptake rate of metals from the dissolved phase (porewater or overlying water). For Ag, approximately 5 to $35 \%$ is due to uptake from the dissolved phase. Our study suggests that the establishment of sediment quality criteria must consider sediment as a potentially important source for metal uptake in benthic invertebrates.
\end{abstract}

KEY WORDS: Bioavailability - Kinetic modeling - Polychaetes - Sediments - Cadmium - Cobalt . Selenium $\cdot$ Silver $\cdot$ Zinc

\section{INTRODUCTION}

There has been considerable interest in assessing the bioavailability of metals from contaminated sediments to marine benthic invertebrates (e.g. Bergman \& Dorward-King 1997, Ingersoll et al. 1997). Sediments are the major repositories of particle-reactive chemical contaminants and can constitute a significant source of contamination to deposit-feeding benthic invertebrates. Many biological and geochemical processes influence metal accumulation in aquatic organisms (Campbell et al. 1988, Luoma 1989). Several geochemical approaches have been applied to study the bioavailability of sediment-bound metals. One approach

\footnotetext{
- Present address: Department of Biology, HKUST, Clear Water Bay, Kowloon, Hong Kong. E-mail: wwang@ust.hk
}

relies on the extraction of metals from oxic sediments with weak acids (e.g. $1 \mathrm{~N} \mathrm{HCl}$ or $\mathrm{HNO}_{3}$ ) (Luoma \& Bryan 1982, Bryan \& Langston 1992) or 'gut juices' prepared in vivo from deposit-feeding animals (Mayer et al. 1996). Metal concentrations in extracted sediments were then correlated with metal concentrations in benthic animals (polychaetes and clams) collected across different gradients of metal contamination in the field. In laboratory studies, metal accumulation in deposit feeders (e.g. Macoma balthica) was measured for sediments with varying geochemical properties (Luoma \& Jenne 1977. Harvey \& Luoma 1985, Decho \& Luoma 1994, Campbell \& Tessier 1997). Another approach quantified the concentrations of acid volatile sulfide (AVS) and simultaneously extracted metal (SEM) in sediments (Di Toro et al. 1993). This approach assumed that metals bound with AVS were not bioavailable to 


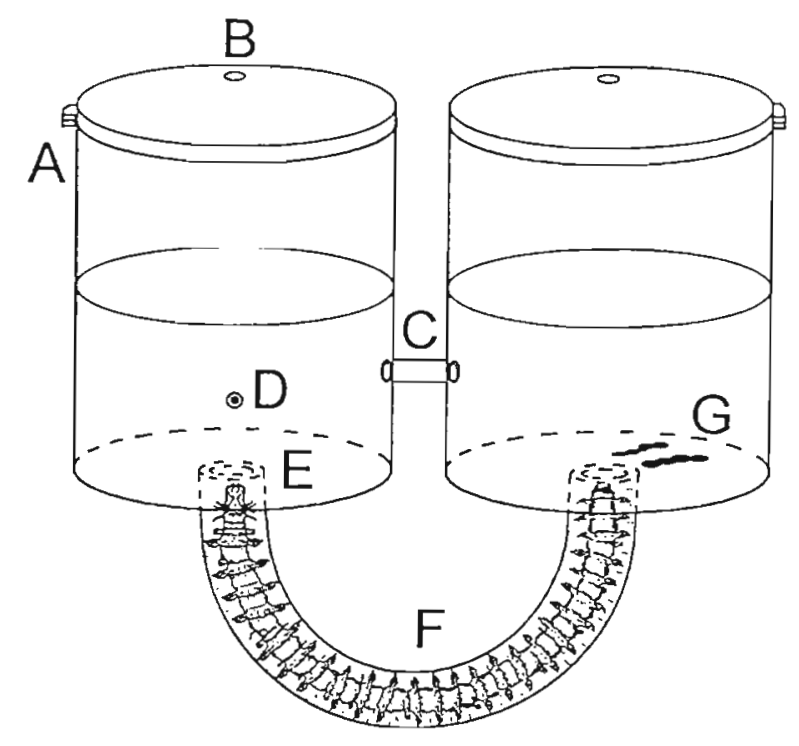

Fig. 1. Schematic drawing of apparatus used in feeding experiments. A: $120 \mathrm{ml}$ polypropylene vial with hinged cap containing $70 \mathrm{ml}$ of filtered seawater; $\mathrm{B}$ : vent hole; $\mathrm{C}$ : tygon connecting tube (3.2 $\mathrm{mm}$ inner diameter); $\mathrm{D}$ : encapsulated radioactive sediment pill; $E$ : head of worm; F: flexible tygon tubing, $3.2 \mathrm{~mm}$ inner diameter; G: radioactive fecal pellets

the animals and that the ratio AVS:SEM controlled metal concentration in sediment porewater (Ankley 1996. Ankley et al. 1996). Few studies have considered the influence of feeding rate or assimilation efficiency of metals from ingested sediments on metal bioaccumulation in deposit-feeding invertebrates.

Benthic animals are exposed to metals in both the solute (including porewater and overlying water) and particulate (sediment) phases. Sediment quality criteria derived from the equilibrium partitioning model are based on the assumption that porewater is the predominant source for metal accumulation and toxicity to benthic invertebrates. This assumption has seldom been tested for benthic invertebrates due to the difficulty in separating the uptake pathways of metal accumulation. Clearly, quantitative assessment of exposure pathways of contaminants for benthic animals is critical for developing improved sediment quality criteria. Significant relationships between metal concentration in animals and acid extracted metal concentration in sediments have been found for some metals (Bryan \& Langston 1992, Luoma \& Fisher 1997). Because deposit feeders ingest sediments at a rate of at least twice their body weight per day to meet nutritional requirements (Cammen 1980a, Lopez \& Levinton 1987), sediments have the potential to be an important source of metals for these animals.

Recently, several studies have demonstrated that the bioenergetic-based kinetic model of contaminant bioaccumulation is a powerful tool to quantitatively sepa- rate pathways of metal uptake in aquatic animals (Luoma et al. 1992, Thomann et al. 1995, Wang et al. 1996. Wang \& Fisher 1997, 1998). In these earlier studies, influx of metals from various sources were experimentally determined and then incorporated into the model to evaluate the relative importance of each uptake pathway. This model is sufficiently flexible in that it can incorporate the variability of each parameter (e.g. assimilation efficiency, feeding rate, metal partition coefficient) that is likely manifested by animals in the field due to varying environmental conditions.

Nereis succinea is a facultative (non-selective) deposit-feeding polychaete that primarily ingests surface oxic sediments, including benthic diatoms and detrital material (Cammen 1980a). In this paper we measured the assimilation efficiencies (AEs) from ingested sediment and the influx rates from the dissolved phase of 5 trace elements ( $\mathrm{Ag}, \mathrm{Cd}, \mathrm{Co}, \mathrm{Se}$ and $\mathrm{Zn}$ ) in these worms. Very few studies have previously measured metal AEs and uptake rates from the dissolved phase in deposit-feeding invertebrates (Wang et al. 1998). Evaluation of AEs is essential in any assessment of metal accumulation in marine invertebrates because AE represents a first order physiological process and can provide an objective basis for assessing metal bioavailability from ingested sediment among species and metals. Further, sensitivity analyses have shown that $\mathrm{AE}$ has a direct and pronounced effect on the metal concentrations in marine invertebrates (Fisher et al. 1996). We employed a kinetic model to quantitatively compare the contribution of solute uptake and sediment ingestion in the overall metal uptake in $N$. succinea.

\section{MATERIALS AND METHODS}

Polychaete worms Nereis succinea of 30 to $50 \mathrm{mg}$ dry wt were collected from the sediments of Flax Pond salt marsh, Long Island, New York, in the summer of 1997 The worms were individually acclimated for 2 to $3 \mathrm{~d}$ (without feeding) in the laboratory in a flexible plastic Utube (inner diameter of $3.2 \mathrm{~mm}$ ). Worms were placed inside the tubes with the aid of a cut-off plastic pipette tip. Both ends of the tube were connected to the bottoms of 2 plastic vials each containing $70 \mathrm{ml}$ of filtered seawater (Fig. 1). A second tube connected both vials to maintain equal hydrostatic pressure between the vials. Details of the experimental apparatus and its application to studying metal uptake in worms are described elsewhere (Wang et al. 1998). All experiments were conducted at $12^{\circ} \mathrm{C}$ with water having a salinity of $28 \mathrm{ppt}$.

Radiolabeling sediments. The purpose of these experiments was to measure the range of AEs of metals from sediments with different characteristics such as 
varying organic content, grain size and redox conditions. Oxic surface sediments collected from Flax Pond (organic carbon content of $5.8 \%$ for particles $<500 \mu \mathrm{m}$ ) and near the Verrazano Bridge (in the Hudson River estuary, organic carbon content of $2.8 \%$ for particles $<500 \mu \mathrm{m}$ ) were used in the experiments. For Flax Pond sediments, we also examined the effects of particle size $(<63 \mu \mathrm{m}$ and 63 to $500 \mu \mathrm{m}$ ) and duration of radiolabeling (sediment aging) on metal AEs in the polychaetes. Metal assimilation from anoxic Flax Pond sediments was also measured. Sediments (about $60 \mathrm{mg}$ wet wt in $2 \mathrm{ml}$ seawater) were radiolabeled with a mixture of radioisotopes: ${ }^{110 m} \mathrm{Ag}+{ }^{109} \mathrm{Cd}+{ }^{57} \mathrm{Co}$ $+{ }^{75} \mathrm{Se}+{ }^{65} \mathrm{Zn}$. Radioisotope additions were $14 \mathrm{kBq}$ for ${ }^{110 \mathrm{~m}} \mathrm{Ag}$ (stock dissolved in $0.1 \mathrm{~N} \mathrm{HNO}_{3}$ ), $17 \mathrm{kBq}$ for ${ }^{109} \mathrm{Cd}$ (in $0.5 \mathrm{~N} \mathrm{HCl}$ ) $7 \mathrm{kBq}$ for ${ }^{57} \mathrm{Co}$ (in $0.1 \mathrm{~N}$ $\mathrm{HCl}, 7 \mathrm{kBq}$ for ${ }^{75} \mathrm{Se}$ (in distilled water, as selenite, $\mathrm{Na}_{2}{ }^{75} \mathrm{SeO}_{3}$ ), and $17 \mathrm{kBq}$ for ${ }^{65} \mathrm{Zn}$ (in $0.1 \mathrm{~N} \mathrm{HCl}$ ). Microliter amounts of $0.5 \mathrm{~N} \mathrm{NaOH}$ were added to maintain the $\mathrm{pH}$ of the seawater at 8.0 . Sediments were labeled for 7,10 or $20 \mathrm{~d}$, respectively, in experiments testing the effects of particle size $(<63 \mu \mathrm{m}$ and 63 to $500 \mu \mathrm{m})$, sediment oxidation state (anoxic and oxic) and particle type (Flax Pond and Verrazano Bridge sediment) on metal assimilation. To test the effects of labeling duration (sediment aging) on metal assimilation, oxic Flax Pond sediments were labeled for periods of 7 to $60 \mathrm{~d}$. Oxic sediments were shaken periodically to maintain oxic conditions throughout the labeling period. Anoxic sediments were collected from a depth $>5 \mathrm{~cm}$ from the Flax Pond salt marsh and were kept in anoxic seawater (bubbled with $\mathrm{N}_{2}$ before addition to sediments) during the labeling period.

Radioactive pulse-chase feeding and depuration. Following radiolabeling, sediments were centrifuged to remove overlying radioactive water. This procedure was performed 3 times by adding non-radioactive filtered seawater after each previous centrifugation. Sediments were then cut into small pieces $(<0.5 \mathrm{mg}$ wet wt) using 2 syringe needles. The sediment placed at the tip of syringe needles was dipped in and out of a plastic ring containing a thin layer of Knox unflavored gelatine $\left(30^{\circ} \mathrm{C}\right)$ and quickly immersed into cold cod liver oil. The quick change in temperature and the hydrophobicity of the oil encapsulated the sediment with a very thin layer of gel (just enough to provide a thin membrane of material to enclose the sediment). Encapsulated anoxic sediments were prepared in a glove bag under an $\mathrm{N}_{2}$ atmosphere. These sediment 'pills' were immediately removed from the oil with a $2 \mathrm{ml}$ pipette, rinsed in cold filtered seawater and placed at the entrance of the plastic U-tube by the worm's head; 2 or 3 pellets were added for each worm. Generally the worms ingested these sediment pills rapidly, and only those individuals which ingested sed- iments within $1 \mathrm{~h}$ were used in the subsequent depuration experiments. In each treatment there were 4 to 6 replicate individuals. Preliminary experiments demonstrated that the gut passage time of food materials in the worm was about $8 \mathrm{~h}$ at $12^{\circ} \mathrm{C}$. The radioactivity of individual worms was immediately determined with 2 min counts, and then the worms were returned to their U-tubes and allowed to purge their ingested radioactive materials for $3 \mathrm{~d}$ by feeding on non-radioactive sediment $(<500 \mu \mathrm{m}, 1 \mathrm{~cm}$ thickness) which was added to the vial at the worm's head side. The egested fecal material was collected in the vial at the tail end (without sediments). The radioactivity remaining in the worms was counted regularly throughout the depuration period. Water in both vials was renewed each day to minimize radioisotope concentrations in the dissolved phase (released from fecal pellets and possible excretion by the worms).

Concern about the effects of encapsulation of radiolabeled sediment in gelatin on trace element assimilation in worms led us to conduct an experiment to test whether the gelatine encapsulation approach had any appreciable effect on the assimilation of the 5 trace elements in Nereis succinea in this study. Radiolabeled sediment (oxic Flax Pond sediment) was prepared as described, half of which was encapsulated in gelatin and half of which was not. For the gelatin-free material, radiolabeled sediment was placed between 2 layers of unlabeled sediment held in $1 \mathrm{~cm}$ silicone tubes ( $6 \mathrm{~mm}$ diam.) and placed near the worm tube opening. For each batch of sediment, 6 worms were allowed to feed and, after $2 \mathrm{~d}$ of depuration, the mass balance approach was used to compare AEs for each trace element. The results indicate there were no significant differences $(p>0.05)$ in AEs for any metal caused by the gelatin encapsulation technique, but Se assimilation was significantly greater $(p<0.05)$ in worms in the absence of a gelatin coating.

Metal desorption from radiolabeled sediments was also measured by resuspending $0.5 \mathrm{mg}$ sediments into $3 \mathrm{ml}$ normal seawater $(0.2 \mu \mathrm{m}$ filtered, $\mathrm{pH} 8.0)$ or acidic seawater $(0.2 \mu \mathrm{m}$ filtered, $\mathrm{pH} 6.0$, by adding $\mathrm{HCl})$. In Nereis succinea $\mathrm{pH}$ values are rather uniform throughout the gut at around 6.1 (M. Ahrens \& G. Lopez, pers. comm.). After 1 d resuspension, sediments were filtered onto $0.2 \mu \mathrm{m}$ polycarbonate membranes, rinsed with $10 \mathrm{ml}$ filtered seawater, and the radioactivity remaining in the sediments was measured.

Metal uptake from the dissolved phase. Metal uptake from the dissolved phase $(<0.2 \mu \mathrm{m})$ was determined by exposing worms at different metal concentrations over time. Concentrations were 0.9, 3.6, 14 and $91 \mathrm{nM}$ for $\mathrm{Ag}$ (added as $\mathrm{AgNO}_{3}$ ), 9, 35, 177 and $708 \mathrm{nM}$ for $\mathrm{Cd}$ (added as $\mathrm{CdCl}_{2}$ ), 17, 68, 339 and $1356 \mathrm{nM}$ for $\mathrm{Co}$ (added as $\mathrm{CoCl}_{2}$ ), 13,51, 253 and $1012 \mathrm{nM}$ for Se 
(added as $\mathrm{Na}_{2} \mathrm{SeO}_{3}$ ) and 31, 123, 385 and $1538 \mathrm{nM}$ for $\mathrm{Zn}$ (added as $\mathrm{ZnCl}_{2}$ ). Both radioisotopes and stable metals were added to filtered seawater (28 ppt) and equilibrated for $16 \mathrm{~h}$ before the dissolved uptake experiments. The amounts of radioisotope additions were $2.8 \mathrm{kBq} \mathrm{l}^{-1}$ for ${ }^{110 \mathrm{~m}} \mathrm{Ag}$ (corresponding to $0.3 \mathrm{nM}$ ) $7.4 \mathrm{kBq}$ $1^{-1}(0.5 \mathrm{nM})$ for ${ }^{109} \mathrm{Cd}_{1} 7.4 \mathrm{kBq} \mathrm{I}{ }^{-1}(0.6 \mathrm{pM})$ for ${ }^{57} \mathrm{Co}, 15 \mathrm{kBq}{ }^{-1}(0.2 \mathrm{nM})$ for ${ }^{75} \mathrm{Se}$, and 11 $\mathrm{kBq} \mathrm{l^{-1 }}(1.3 \mathrm{nM})$ for ${ }^{65} \mathrm{Zn}$. There were 5 replicate worms for each concentration treatment. Worms were individually placed in $80 \mathrm{ml}$ seawater containing both radiotracer and stable metals. Periodically, each worm was removed from the radiolabeled water, rinsed with filtered seawater and counted for their radioactivity for $2 \mathrm{~min}$. They were then returned to new batches of seawater containing the same metal concentration. After exposure to metals for $34 \mathrm{~h}$, worms were then dried at $80^{\circ} \mathrm{C}$ for $1 \mathrm{~d}$ and their dry weights were determined.

Radioactivity measurements. Radioactivity of ${ }^{110 \mathrm{~m}} \mathrm{Ag},{ }^{109} \mathrm{Cd},{ }^{57} \mathrm{Co},{ }^{75} \mathrm{Se}$ and ${ }^{65} \mathrm{Zn}$ in the samples was measured with a Pharmacia-Wallac LKB 1282 Compugamma equipped with a $\mathrm{NaI}(\mathrm{Tl})$ well detector. All measurements were related to appropriate standards and calibrated for radioisotope spillover from one isotope's energy window into another's. The gamma emission of ${ }^{110 \mathrm{~m}} \mathrm{Ag}$ was determined at $658 \mathrm{keV}$. of ${ }^{109} \mathrm{Cd}$ at $88 \mathrm{keV}$, of ${ }^{57} \mathrm{Co}$ at $122 \mathrm{keV}$ of ${ }^{75} \mathrm{Se}$ at $264 \mathrm{keV}$. and of ${ }^{65} \mathrm{Zn}$ at $1115 \mathrm{keV}$. Counting times in all samples were adjusted to give propagated counting errors $<5 \%$ for each isotope.

Kinetic separation of the uptake pathways of metals in the polychaetes. In the bioenergetic-based kinetic model (Thomann 1981, Wang et al. 1996, Wang \& Fisher 1997), metal concentrations in polychaetes under steadystate conditions $\left(C_{\mathrm{ss}}, \mu \mathrm{g} \mathrm{g}^{-1}\right)$ can be described by:

$$
\begin{aligned}
C_{s s} & =\frac{\left(k_{\mathrm{u}} \times C_{\mathrm{w}}\right)+\left(\mathrm{AE} \times \mathrm{IR} \times C_{f}\right)}{\left(k_{e}+g\right)} \\
C_{s 5, \mathrm{w}} & =\frac{\left(k_{u} \times C_{\mathrm{w}}\right)}{\left(k_{e}+g\right)} \\
C_{\text {ss.f }} & =\frac{\left(\mathrm{AE} \times \mathrm{IR} \times C_{f}\right)}{\left(k_{e}+g\right)}
\end{aligned}
$$

where $C_{s s, w}$ is the metal concentration in worms due to uptake from the solute phase, $C_{s s, 1}$ is the metal concentration in worms due to uptake from the sediments, $k_{u}$ is the metal uptake rate constant from the dissolved phase $\left(\mathrm{l} \mathrm{g}^{-1} \mathrm{~d}^{-1}\right), C_{\mathrm{w}}$ is the metal concentration in the
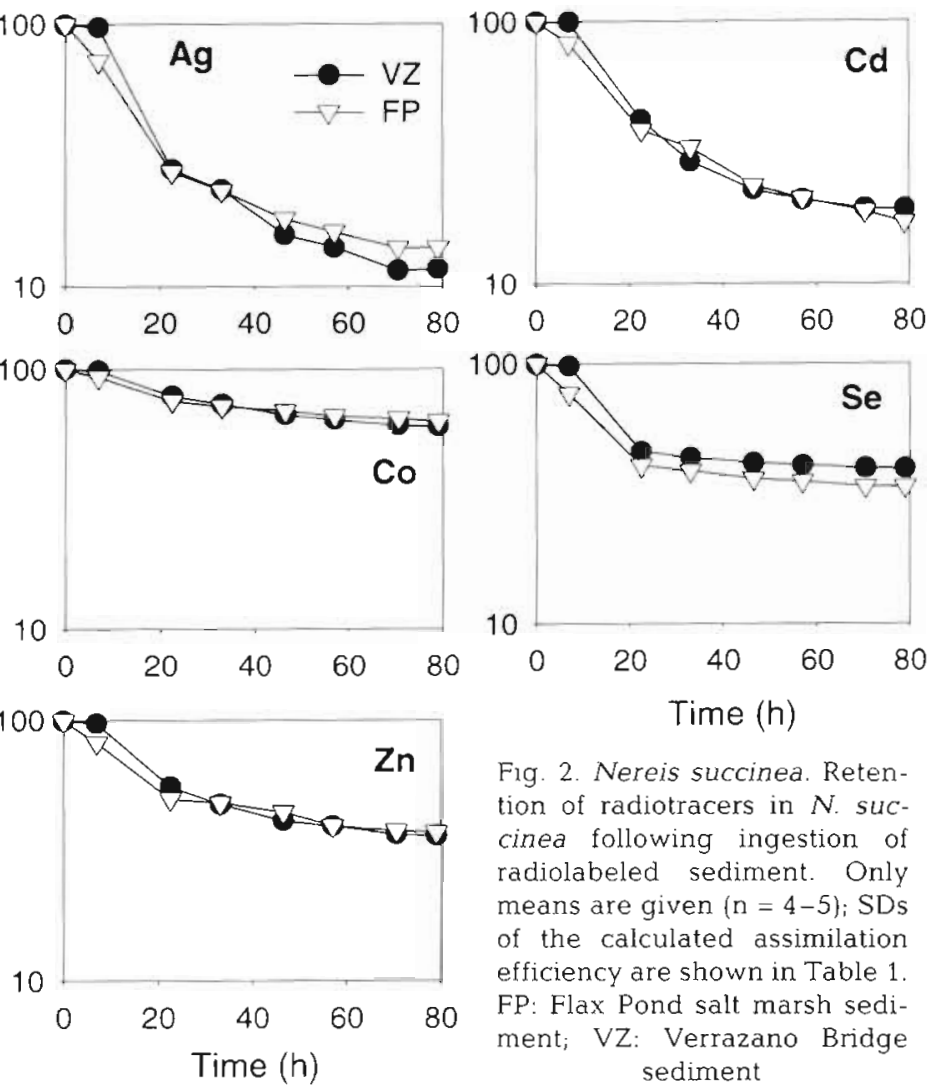

Fig. 2. Nereis succinea. Retention of radiotracers in $N$. succinea following ingestion of radiolabeled sediment. Only means are given $(n=4-5)$; SDs of the calculated assimilation efficiency are shown in Table 1. FP: Flax Pond salt marsh sediment; VZ: Verrazano Bridge sediment

dissolved phase $\left(\mu \mathrm{g} \mathrm{l}^{-1}\right), \mathrm{AE}$ is the assimilation efficiency from ingested sediment (\%), IR is the ingestion rate of the worms $\left(\mathrm{g} \mathrm{g}^{-1} \mathrm{~d}^{-1}\right), C_{1}$ is the metal concentration in ingested sediments $\left(\mu \mathrm{g} \mathrm{g}^{-1}\right), k_{e}$ is the metal efflux rate constant $\left(\mathrm{d}^{-1}\right)$ (assuming that efflux rates are the same following uptake from dissolved and particulate phases) and $g$ is the growth rate constant of the worms $\left(\mathrm{d}^{-1}\right)$. This model also assumes that uptake from both the solute and particulate phases is additive (see discussion in Luoma \& Fisher 1997). If $C_{f}$ cannot be measured directly, it can be calculated from the following equation:

$$
C_{1}=K_{d} \times C_{w}
$$

where $K_{\mathrm{d}}$ is the partition coefficient $\left(\mathrm{l} \mathrm{g}^{-1}\right)$ of the metal in the sediments. Thus Eq. (3) can be expressed as:

$$
C_{s s, f}=\frac{\left(A E \times I R \times C_{w} \times K_{d}\right)}{\left(k_{e}+g\right)}
$$

The fractions of total accumulated metal obtained from the dissolved phase (including porewater and overlying water, $R_{w}$ ) and from the particulate phase (sediment, $R_{f}$ ) can therefore be calculated as:

$$
\begin{aligned}
R_{\mathrm{w}} & =k_{\mathrm{u}} /\left(k_{\mathrm{u}}+\mathrm{AE} \times \mathrm{IR} \times K_{\mathrm{d}}\right) \\
R_{\mathrm{f}} & =1-R_{\mathrm{w}}
\end{aligned}
$$




\section{RESULTS}

\section{Assimilation efficiencies of metals in worms}

Metal depuration in Nereis succinea following ingestion of the different radiolabeled sediments is shown in Figs, 2 to 5. Significant egestion of radioactive fecal pellets was evident after $8 \mathrm{~h}$ of depuration. Egestion of most unassimilated metals was complete within $45 \mathrm{~h}$. AEs were calculated using 2 methods (Wang et al. 1998). The first method (mass balance) assumed that worms completed metal assimilation within $45 \mathrm{~h}$, and the percentage of ingested radioisotope that was retained in the worms after $45 \mathrm{~h}$ of depuration was considered as the $\mathrm{AE}$. The second method modeled the depuration of radioisotope in the more slowly exchanging compartment (between 45 and 79 h), and the $\mathrm{AE}$ was calculated as the $y$-intercept of the regression between the log of the percentage of radioisotope retained in worms and the time of depuration (45 to $79 \mathrm{~h}$ ), according to the following equation:

$$
A=A E \times \mathrm{e}^{(-b \times t)}
$$

where $A$ is the percentage of the ingested radioactivity retained in the worm at each sample time (between 45 and 79 h of depuration), $\mathrm{AE}$ is the assimilation efficiency, $t$ is time $(h)$ of depuration and $b$ is the depuration rate constant $\left(\mathrm{h}^{-1}\right)$.

Appreciable assimilation, calculated by both methods, was found for all metals from radiolabeled sediments (Table 1). Generally, AEs calculated by the mass balance method were slightly higher than AEs determined by the regression method. AEs of $\mathrm{Co}, \mathrm{Se}$, and $\mathrm{Zn}$ were somewhat higher than those of $\mathrm{Ag}$ and Cd. No significant differences in metal AEs were found between Verrazano and Flax Pond sediments or between $<63 \mu \mathrm{m}$ and 63 to $500 \mu \mathrm{m}$ sediments, implying that sediments from different locations (with different organic carbon content) and particle size had little influence on metal assimilation in Nereis succinea. With the exception of Se, metals from anoxic sediments were assimilated by the worms with a significantly lower efficiency than
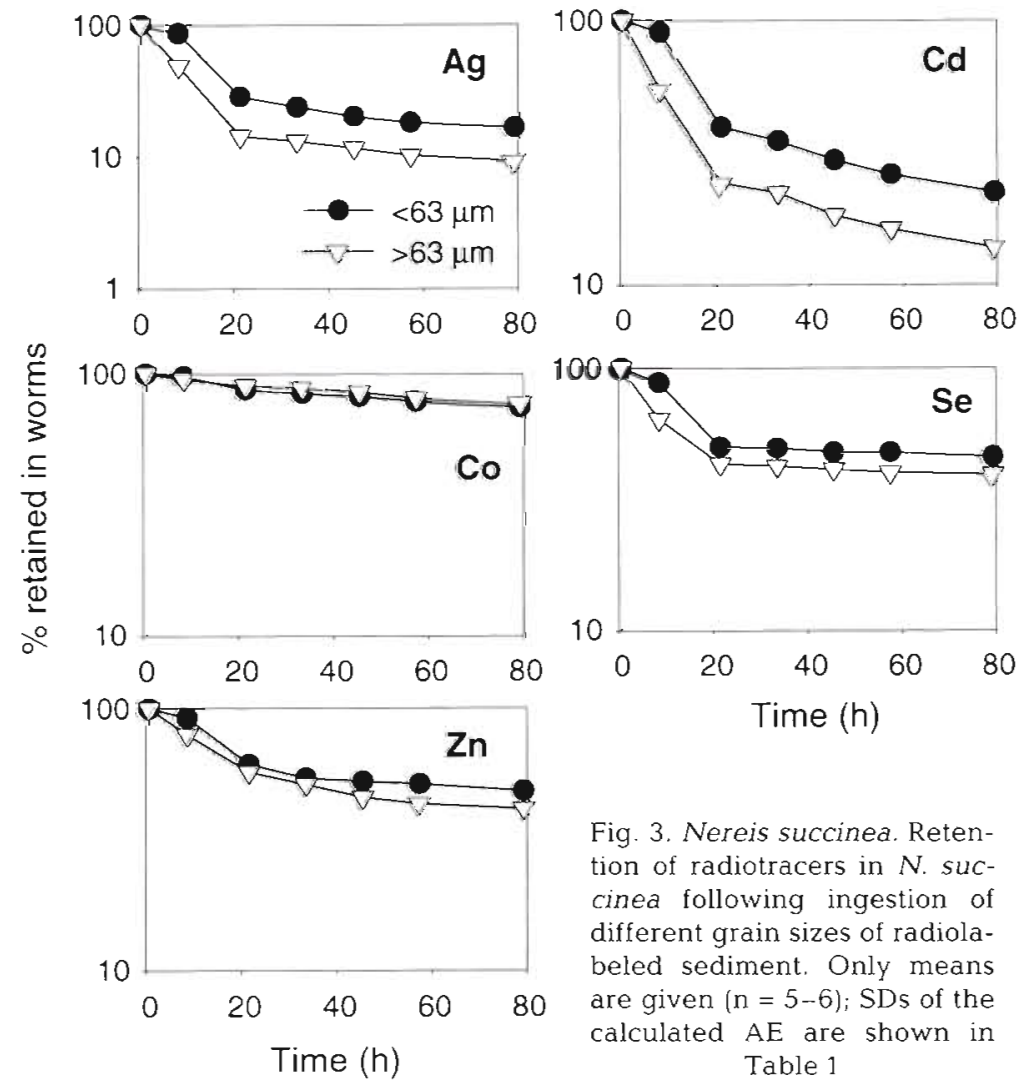

Fig. 3. Nereis succinea. Retention of radiotracers in $N$. succinea following ingestion of different grain sizes of radiolabeled sediment. Only means are given $(n=5-6)$; SDs of the calculated $\mathrm{AE}$ are shown in Table 1
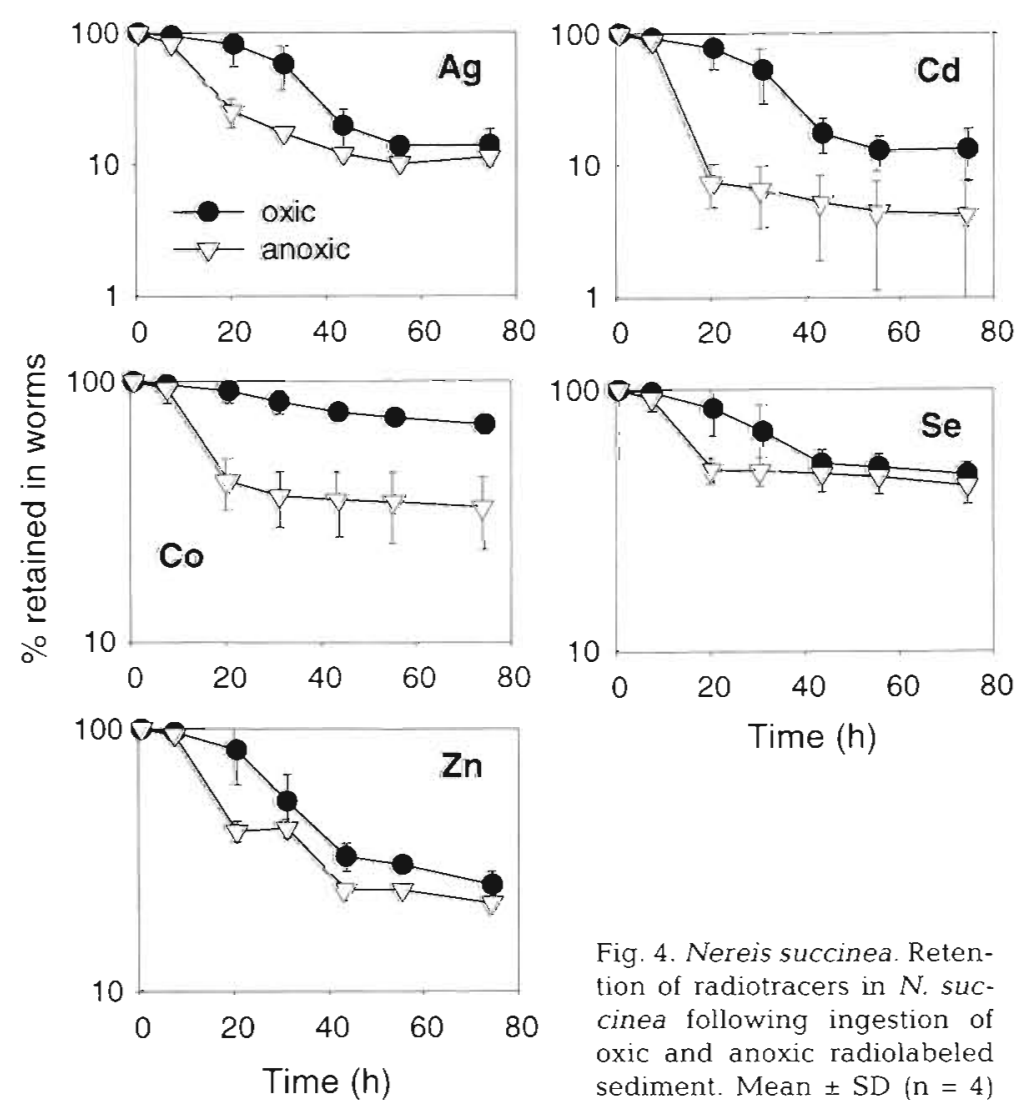

Fig. 4. Nereis succinea. Retention of radiotracers in $N$. succinea following ingestion of oxic and anoxic radiolabeled sediment. Mean $\pm S D(n=4)$ 
metals associated with oxic sediments $(\mathrm{p}<$ $0.05)$. The greatest effect was found for $\mathrm{Cd}$ and $\mathrm{Co}$ (2-to 3 -fold difference between oxic and anoxic sediments), whereas for Ag and $\mathrm{Zn}$ this difference was smaller, but statistically significant.

The effects of sediment radiolabeling time (from 7 up to $60 \mathrm{~d}$ ) on metal assimilation varied among the metals. No major difference was found for $\mathrm{Ag}, \mathrm{Co}, \mathrm{Se}$ and $\mathrm{Zn}$, but duration of sediment radiolabeling significantly affected Cd assimilation ( $p<0.05$, Model I, ANOVA). Cd assimilation decreased by up to 2.8-fold for sediments labeled for $60 \mathrm{~d}$ (Table 1).

Significant metal desorption occurred when the radiolabled sediments were resuspended into $\mathrm{pH} 8.0$ or $\mathrm{pH} 6.0$ seawater for $1 \mathrm{~d}$. Lowering the $\mathrm{pH}$ from 8.0 to 6.0 also enhanced metal desorption, except for Se (Fig. 6). There was no correlation between metal AEs in worms and the percentage of metal desorption from radiolableled sediments (Fig. 6).

\section{Metal uptake from the dissolved phase}

Metal uptake from the dissolved phase over exposure time is shown in Fig. 7. Because radioactive water was renewed every few hours, there was only a very small decline $(<5 \%)$ in the dissolved metal concentration due to worm uptake during the exposure period. The worms showed a linear pattern of metal uptake between 2 and $10.5 \mathrm{~h}$, after which the rate of metal uptake decreased slightly (except for Se which had a linear pattern of uptake between 2 and $33.5 \mathrm{~h})$. The uptake rate constants of metals from the dissolved phase $\left(k_{\mathrm{u}}, \mathrm{l} \mathrm{g}^{-1} \mathrm{~d}^{-1}\right)$ were therefore calculated using data obtained between 2 and $10.5 \mathrm{~h}$.

To calculate $k_{u}$, we first calibrated for surface adsorption of metals during the first $2 \mathrm{~h}$ of exposure. A linear regression between metal uptake and exposure time was performed between 2 and $10.5 \mathrm{~h}$, and the calculated $y$-intercept was assumed to be the amount of metal adsorbed onto the worm's surface. This amount was then subtracted from the metal uptake between 2 and $10.5 \mathrm{~h}$ to calculate the net metal uptake. Influx rates of metals $\left(I_{u}, \mu \mathrm{g} \mathrm{g}^{-1} \mathrm{~d}^{-1}\right)$ in worms were therefore calculated at 2,6 and $10.5 \mathrm{~h}$ of
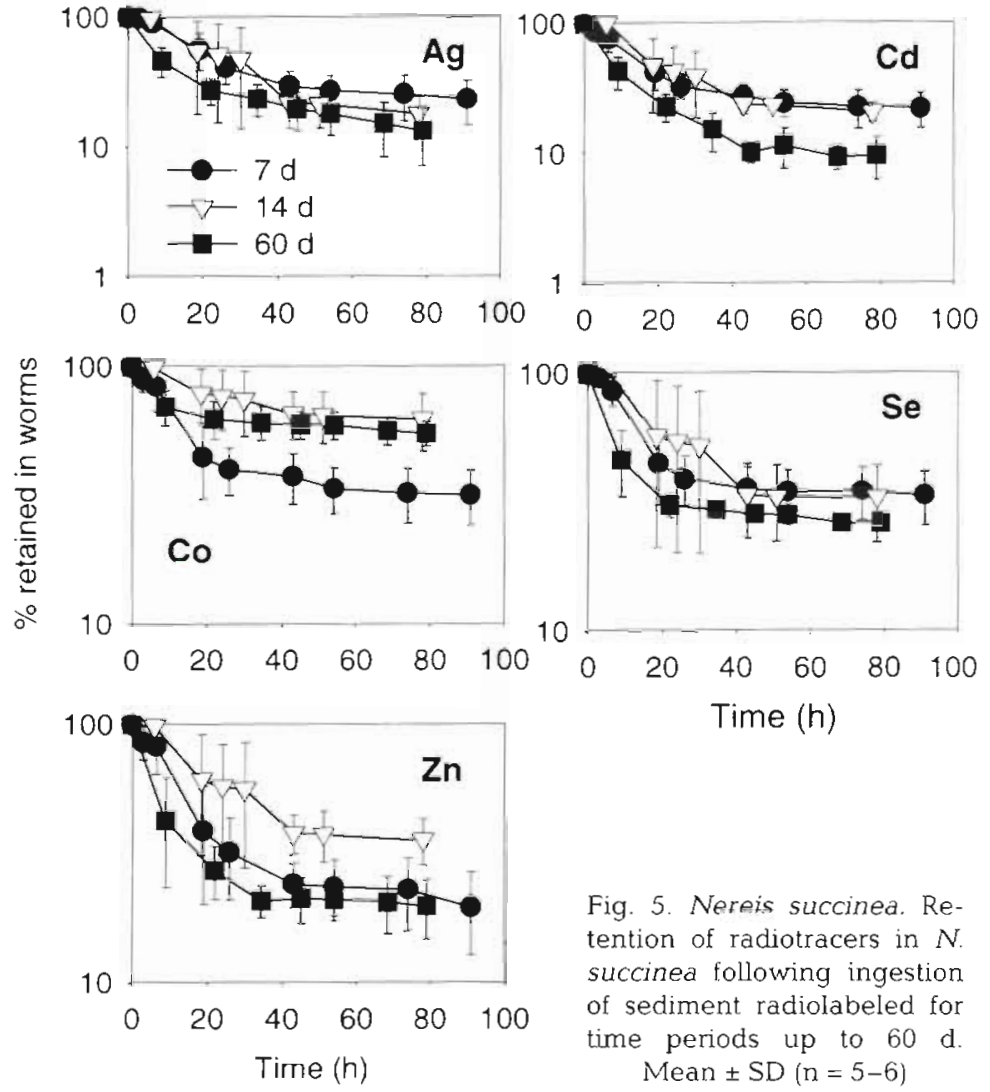

Fig. 5. Nereis succinea. Retention of radiotracers in $N$. succinea following ingestion of sediment radiolabeled for time periods up to $60 \mathrm{~d}$. Mean \pm SD $(n=5-6)$
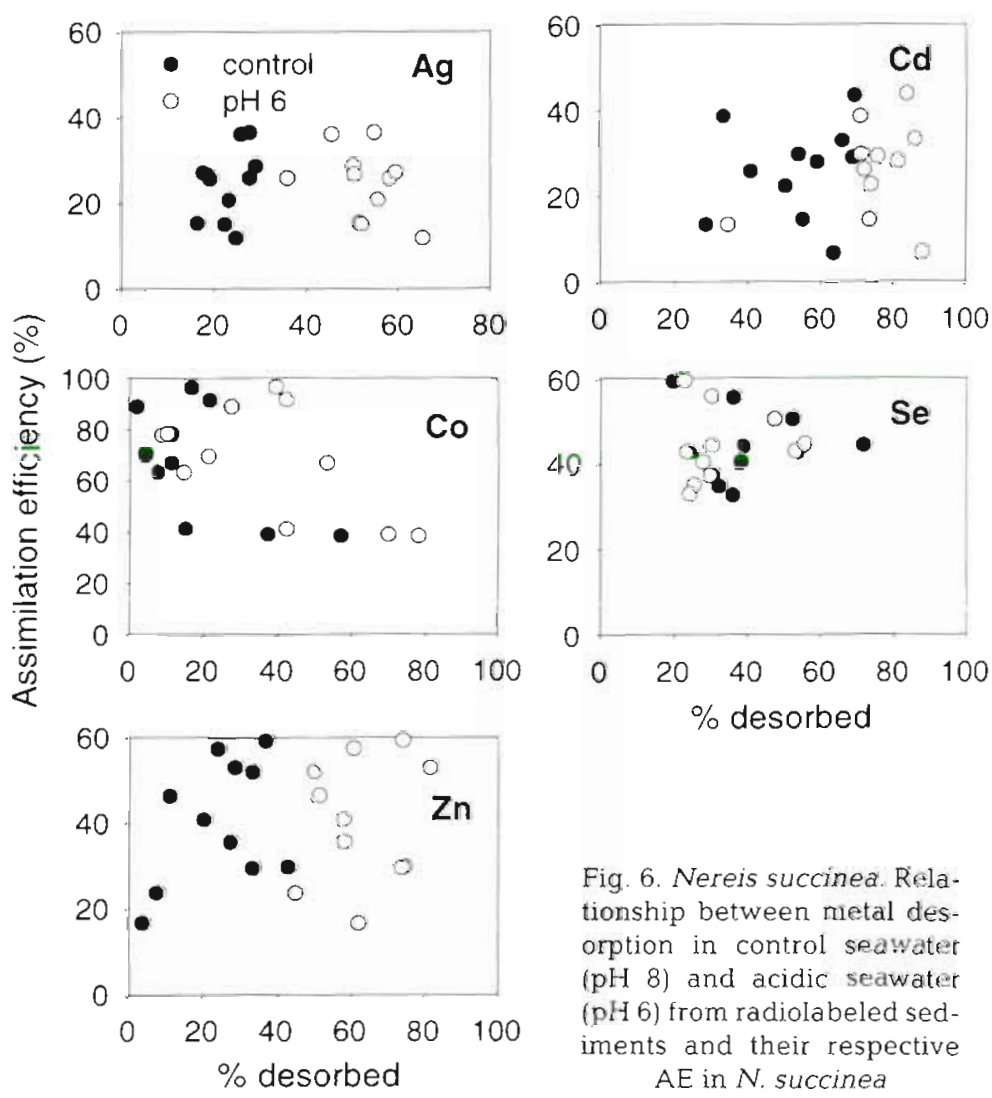

Fig. 6. Nereis succinea. Relationship between metal desorption in control seawater $(\mathrm{pH}$ 8) and acidic seawater $(\mathrm{pH}$ 6) from radjolabeled sediments and their respective AE in $N$. succinea 
Table 1. Nereis succinea. Assimilation efficiencies (AEs) of trace elements (means $\pm \mathrm{SD}, \mathrm{n}=4-6$ ) in the polychaete feeding on different types of sediments (MB: mass balance method, assumes that metal assimilation was complete after $45 \mathrm{~h}$ of depuration; $\mathrm{R}$; regression method, using the $y$-intercept). Statistically significant difference in metal assimilation between treatments ( $t$-test) or among treatments (ANOVA test) is indicated in parentheses: " $p<0.05$ and $" p<0.01$

\begin{tabular}{|c|c|c|c|c|c|c|}
\hline Expt & $\begin{array}{c}\mathrm{AE} \\
\text { method }\end{array}$ & $\mathrm{Ag}$ & $\mathrm{Cd}$ & $\mathrm{Co}$ & $\mathrm{Se}$ & $\mathrm{Zn}$ \\
\hline \multicolumn{7}{|c|}{ Flax Pond vs Verrazano Bridge sediment } \\
\hline \multirow[t]{2}{*}{ Flax Pond } & $\mathrm{MB}$ & $18.2 \pm 4.8$ & $23.9 \pm 6.4$ & $69.5 \pm 14.9$ & $36.3 \pm 6.5$ & $44.6 \pm 6.1$ \\
\hline & $\mathrm{R}$ & $26.7 \pm 6.3$ & $39.0 \pm 14.7$ & $78.6 \pm 14.5$ & $40.4 \pm 7.9$ & $57.3 \pm 17.4$ \\
\hline \multirow[t]{2}{*}{ Verrazano } & $\mathrm{MB}$ & $15.8 \pm 2.6$ & $22.9 \pm 4.5$ & $67.1 \pm 11.0$ & $41.8 \pm 6.5$ & $41.3 \pm 6.2$ \\
\hline & $\mathrm{R}$ & $26.0 \pm 7.3$ & $29.3 \pm 7.5$ & $78.1 \pm 11.8$ & $44.8 \pm 7.1$ & $51.9 \pm 6.1$ \\
\hline \multicolumn{7}{|c|}{$<63 \mu \mathrm{m}$ vs $63-500 \mu \mathrm{m}$ sediment } \\
\hline \multirow[t]{2}{*}{$<63 \mu \mathrm{m}$} & $\mathrm{MB}$ & $20.0 \pm 8.1$ & $29.3 \pm 9.2$ & $81.3 \pm 8.4$ & $47.6 \pm 8.7$ & $52.6 \pm 12.1$ \\
\hline & $\mathrm{R}$ & $25.8 \pm 8.7$ & $43.8 \pm 12.5$ & $91.6 \pm 8.1$ & $50.7 \pm 9.1$ & $59.2 \pm 14.2$ \\
\hline \multirow[t]{2}{*}{$63-500 \mu \mathrm{m}$} & MB & $11.6 \pm 6.4$ & $18.1 \pm 8.1$ & $84.7 \pm 7.6$ & $40.8 \pm 6.6$ & $45.6 \pm 17.3$ \\
\hline & $\mathrm{R}$ & $15.4 \pm 7.3$ & $28.2 \pm 7.6$ & $96.5 \pm 1.2$ & $43.0 \pm 6.4$ & $53.0 \pm 15.0$ \\
\hline \multicolumn{7}{|c|}{ Oxic vs anoxic sediment } \\
\hline \multirow[t]{2}{*}{ Oxic } & MB & $19.5 \pm 6.6$ & $17.4 \pm 5.2$ & $76.1 \pm 5.5$ & $52.0 \pm 6.7$ & $32.4 \pm 4.0$ \\
\hline & $\mathrm{R}$ & $27.3 \pm 7.5$ & $26.1 \pm 7.8$ & $89.1 \pm 12.5$ & $59.6 \pm 9.4$ & $46.3 \pm 5.0$ \\
\hline \multirow[t]{2}{*}{ Anoxic } & MB & $11.9 \pm 0.3$ & $5.2 \pm 3.2$ & $35.1 \pm 9.8$ & $47.6 \pm 7.0$ & $24.2 \pm 0.5$ \\
\hline & $\mathrm{R}$ & $\begin{array}{c}12.0 \pm 1.5 \\
(*)\end{array}$ & $\begin{array}{c}6.9 \pm 2.8 \\
(")\end{array}$ & $\begin{array}{c}38.7 \pm 9.2 \\
\cdots\end{array}$ & $55.8 \pm 8.3$ & $\begin{array}{c}29.4 \pm 2.8 \\
(*)\end{array}$ \\
\hline \multicolumn{7}{|c|}{ Radiolabeling duration of sediment } \\
\hline \multirow[t]{2}{*}{$7 \mathrm{~d}$} & MB & $30.0 \pm 8.6$ & $28.0 \pm 6.3$ & $37.6 \pm 8.3$ & $36.0 \pm 7.4$ & $24.2 \pm 4.7$ \\
\hline & $\mathrm{R}$ & $36.6 \pm 8.7$ & $33.3 \pm 7.9$ & $41.6 \pm 8.2$ & $37.6 \pm 6.6$ & $29.8 \pm 2.6$ \\
\hline \multirow[t]{2}{*}{$14 \mathrm{~d}$} & $\mathrm{MB}$ & $22.1 \pm 8.2$ & $24.4 \pm 4.0$ & $65.7 \pm 13.8$ & $34.0 \pm 11.0$ & $37.8 \pm 6.5$ \\
\hline & $\mathrm{R}$ & $28.8 \pm 11.3$ & $30.0 \pm 4.9$ & $69.8 \pm 11.4$ & $35.0 \pm 11.2$ & $40.9 \pm 7.1$ \\
\hline \multirow[t]{2}{*}{$60 \mathrm{~d}$} & $\mathrm{MB}$ & $20.0 \pm 6.6$ & $10.4 \pm 1.9$ & $59.6 \pm 7.1$ & $28.7 \pm 2.2$ & $21.2 \pm 4.3$ \\
\hline & $\mathrm{R}$ & $36.2 \pm 6.8$ & $\begin{array}{c}13.6 \pm 3.3 \\
(\cdot)\end{array}$ & $67.2 \pm 9.3$ & $32.9 \pm 4.2$ & $23.8 \pm 3.2$ \\
\hline
\end{tabular}

exposure, and the mean influx rate was calculated based on these 3 time point measurements. Finally, $I_{u}$ was correlated with metal concentration in the dissolved phase $\left(C_{\mathrm{w}}\right)$ (Fig. 8).

A linear relationship between $\log I_{\mathrm{u}}$ and $\log C_{w}$ was found for each metal (Fig. 8), suggesting that metal uptake from the dissolved phase conformed with Freundlich adsorption isotherms. For Ag, Co and Se, the coefficients describing the relationships between $\log I_{\mathrm{u}}$ and $\log C_{\mathrm{w}}$ were close to 1 ; thus their $k_{\mathrm{u}}$ can be directly calculated as the antilog of the intercept between $\log I_{\mathrm{u}}$ and $\log C_{\mathrm{w}}$. However, the coefficients were only 0.776 for $C d$ and 0.603 for $\mathrm{Zn}$, suggesting that these 2 metals were regulated during their uptake from the dissolved phase. To calculate the $k_{u}$ for these 2 metals, we regressed $\mathrm{I}_{\mathrm{u}}$ and $C_{\mathrm{w}}$ (without log-transformation) by forcing the $y$-intercept through zero. Among the 5 elements, Ag had the highest $k_{u}$, followed by $\mathrm{Zn}>\mathrm{Co}>\mathrm{Cd}>$ Se (Fig. 8).
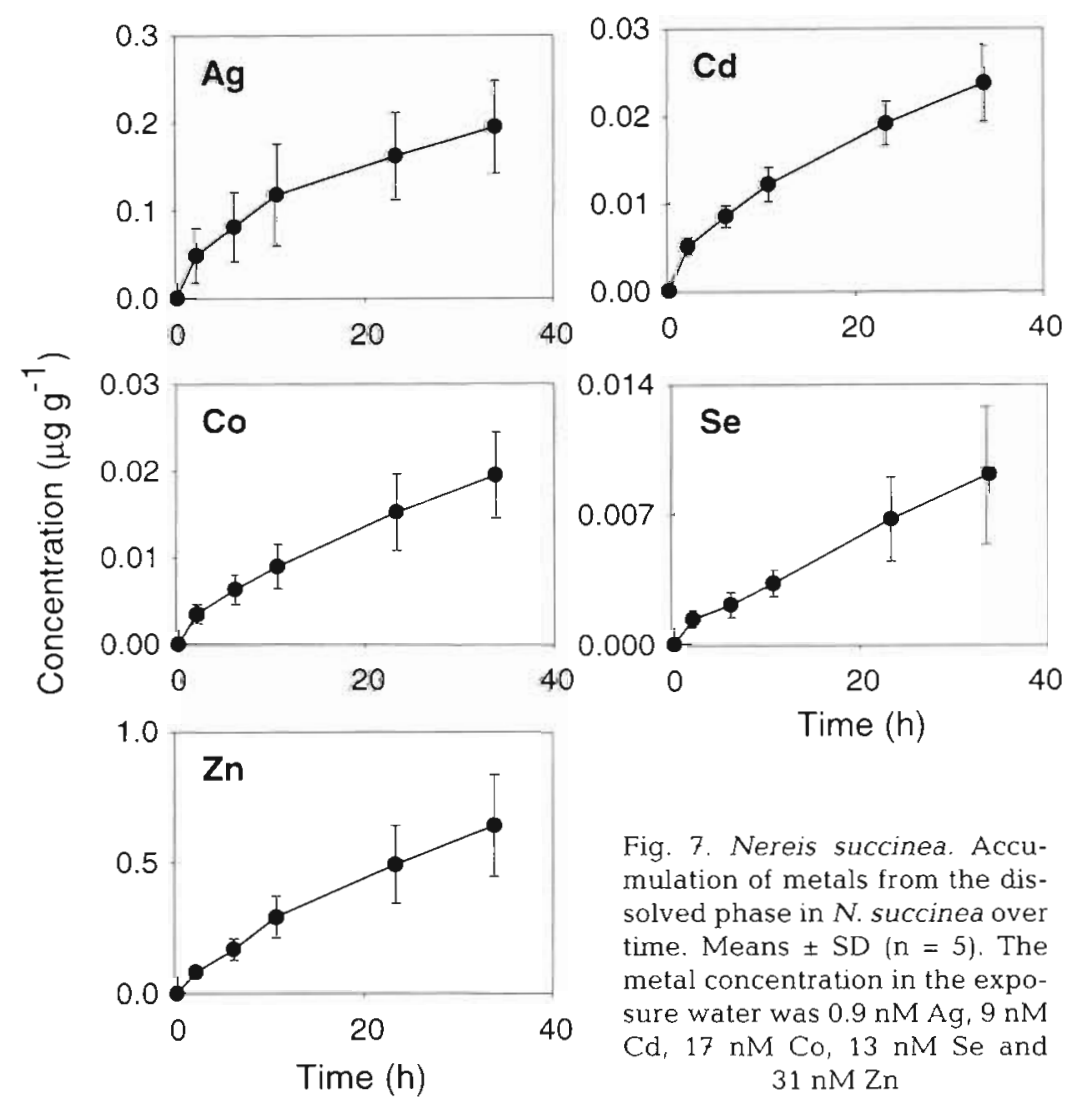

Fig. 7. Nereis succinea. Accumulation of metals from the dissolved phase in $N$. succinea over time. Means \pm SD $(n=5)$. The metal concentration in the exposure water was $0.9 \mathrm{nM} \mathrm{Ag}, 9 \mathrm{nM}$ $\mathrm{Cd}, 17 \mathrm{nM}$ Co, $13 \mathrm{nM}$ Se and $31 \mathrm{nM} \mathrm{Zn}$ 

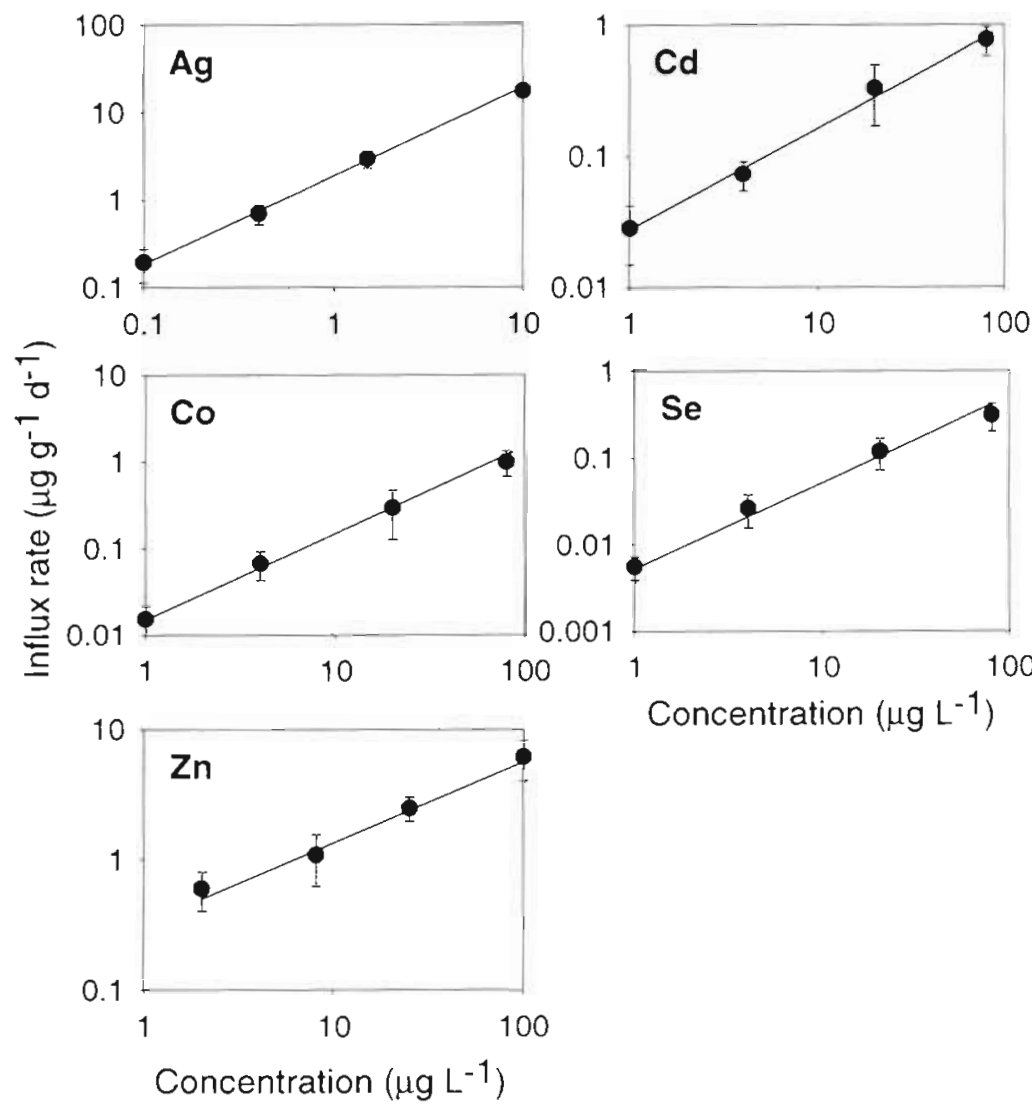

Fig. 8. Nereis succinea. Influx rates of metals into $N$. succinea at different dissolved metal concentrations. Means $\pm \mathrm{SD}(\mathrm{n}=5)$. Relationships describing metal influx rate $\left(I_{u}\right)$ and metal concentration in the dissolved phase $\left(C_{w^{\prime}}\right)$ were: for Ag, $I_{\mathrm{u}}=1.853\left[C_{\mathrm{w}}\right]^{0.986 \pm 0.019}\left(\mathrm{r}^{2}=0.999\right)_{\text {; }}$ for $C \mathrm{Cd}_{1} I_{\mathrm{u}}=0.028\left[C_{\mathrm{w}}\right]^{0776 \pm 0044}$ $\left(\mathrm{r}^{2}=0.994\right) ;$ for Co, $I_{u}=0.016\left[C_{\mathrm{w}}\right]^{0.35: \pm 0.030}\left(\mathrm{r}^{2}=0.998\right)$; for Se, $I_{u}=$ $0.006\left[C_{\mathrm{w}}\right]^{0.919 \pm 0.064}\left(\mathrm{r}^{2}=0.990\right)$; for $\mathrm{Zn}, I_{\mathrm{u}}=0.359\left[C_{\mathrm{w}}\right]^{0.603 \pm 0.047}\left(\mathrm{r}^{2}=0.988\right)$. The calculated uptake rate constants $\left(k_{\mathrm{u}}, \mathrm{lg}^{-1} \mathrm{~d}^{-1}\right)$ from the dissolved phase were 1.853 for $\mathrm{Ag}, 0.010$ for $\mathrm{Cd}, 0.016$ for $\mathrm{Co}, 0.006$ for Se and 0.064 for $\mathrm{Zn}$. Values of $k_{u}$ for $\mathrm{Cd}$ and $\mathrm{Zn}$ were calculated based on linear regression of $I_{u}$ and $C_{\mathrm{w}}$ without $\log$-transformation

\section{Evaluation of metal uptake pathways in worms}

According to Eqs. (6) \& (7), $k_{\mathrm{u}}, \mathrm{AE}, \mathrm{IR}$ and $K_{\mathrm{d}}$ are parameters required to quantify the relative importance of dissolved metal and sediment as sources for metal accumulation in worms. Ranges of AEs (calculated by the mass balance method) for each metal were taken from Table 1 and values of $k_{u}$ were taken from Fig. 8. For our model calculations, we used a mean weight-specific ingestion rate for Nereis succinea of $3.5 \mathrm{~g} \mathrm{~g}^{-1} \mathrm{~d}^{-1}$ (Cammen 1980b) and mean metal $K_{\mathrm{d}}$ values for coastal surface sediments (IAEA 1985). However, because metal $A E$ and sediment $K_{d}$ values may vary considerably under different environmental conditions, we also performed a sensitivity analysis to determine the effects of $A E$ and $K_{d}$ variation on the relative importance of dissolved and particulate (sedi- ment) uptake. The mean numerical value of each parameter is given in the legend of Fig. 9.

Our calculations suggest that under conditions typical of natural environments, most of the body burden (>98\%) of $\mathrm{Cd}, \mathrm{Co}, \mathrm{Se}$ and $\mathrm{Zn}$ in Nereis succinea is obtained by ingestion of sediment and that varying $A E$ and $K_{d}$ have little effect (Fig. 9). For example, even an AE as low as $1 \%$ (below any $\mathrm{AE}$ measured in our study) will result in $88 \%$ of $\mathrm{Cd}, 100 \%$ of $\mathrm{Co}, 85 \%$ of Se and $92 \%$ of $\mathrm{Zn}$ coming from ingestion of sediments. Ag is the only metal which shows notable uptake from the dissolved phase, but its uptake is also dominated by ingestion of sediments ( 65 to $95 \%$ ). The relative importance of dissolved uptake and uptake from sediment is highly dependent on $\mathrm{Ag} \mathrm{AE}$ in the worms and $\mathrm{Ag} K_{\mathrm{d}}$ in the sediments (Fig. 9).

\section{DISCUSSION}

\section{Metal assimilation from sediments}

$A E$ is a critical parameter determining metal bioavailability from sediments, but very few studies have made such measurements for marine deposit feeders. Ranges of AEs for 5 trace elements observed in Nereis succinea were comparable to other invertebrates (Wang et al. 1996. Wang \& Fisher 1997). AEs of Se and $\mathrm{Zn}$ were higher than the other metals such as Ag and Cd which have no biological function. For $\mathrm{Co}$, AEs were as high as $85 \%$ in several experiments; Co AEs in marine suspension feeders are generally in the range of 10 to $50 \%$ (Reinfelder et al. 1997, Wang \& Fisher 1997, 1998). In addition, AEs measured by the 2 methods were comparable, although in some cases AEs were lower when determined by the mass balance method than by the regression method. This may be due to the inclusion of some post-digestive excretion of metals (e.g. physiological turnover) when the AE was calculated by the mass balance method.

Our results demonstrated that with the exception of Se, the gelatine encapsulation technique did not significantly alter metal bioavailability in Nereis succinea. Metal AEs were comparable in worms feeding on encapsulated sediments (thin layer) and sediments in the absence of a gelatin coating. Similarly, Wallace \& Lopez (1997) measured Cd assimilation by shrimp 
Palaemontes pugio fed gelatine-embedded homogenized oligochaetes Limnodrilus hoffmeisteri and demonstrated that $\mathrm{Cd}$ AEs measured by this technique were similar to those measured for shrimps fed single whole worms, suggesting that gelatine embedding did not alter Cd bioavailability in shrimp either.

Variability of metal AEs among sediment types was smaller than intra-elemental differences. Our study suggests that both particle size and organic carbon content of sediments have little influence on metal assimilation in these polychaetes. In field studies, particle size and sediment organic carbon content were found to inversely influence metal concentration in marine deposit feeders (Bryan \& Langston 1992). Because metal bioaccumulation is also determined by an animal's feeding rate and by the metal concentration in ingested food particles, we suggest that these factors are responsible for the relationship between metal bioaccumulation and organic carbon content and particle size. Particle selectivity of deposit-feeding animals can considerably affect the accumulation of organic contaminants (Lydy \& Landrum 1993, Kukkonen \& Landrum 1995, Forbes \& Forbes 1997). These animals can selectively ingest finer grained, organicrich particles and because of the higher contaminant concentration associated with these particles, contaminant influx from the ingested particles will increase disproportionately. Nereis succinea is a facultative deposit feeder and shows little evidence of particle selectivity in feeding (Cammen 1980a).

Metals, especially $\mathrm{Cd}$ and Co, associated with anoxic sediments were generally less bioavailable to Nereis succinea than metals associated with oxic sediments. The lower metal bioavailability from anoxic sediments was probably due to a greater proportion of metal bound to insoluble sulfides in these sediments. The strong binding of metals with acid volatile sulfides (AVS) in contaminated sediments has been reported to control metal bioavailability and toxicity to benthic invertebrates (Di Toro et al. 1993, Ankley 1996. Ankley et al. 1996). In our experiments, anoxic sediments were radiolabeled for $10 \mathrm{~d}$. Because binding of the radiolabeled metals with AVS was not measured, our experiments did not necessarily indicate that metals bound with AVS were directly bioavailable to the worms, but this possibility cannot be ruled out. It is likely that metals associated with sediments can undergo considerable changes in chemical conditions within the gut of $N$. succinea during the long metal residence time (about 2 d). For example, some metals bound with AVS may be re-oxidized within the gut and be assimilated across the gut lining. Appreciable assimilation of metals from anoxic sediment has also been measured in marine mussels and clams (Griscom \& Fisher unpubl.).

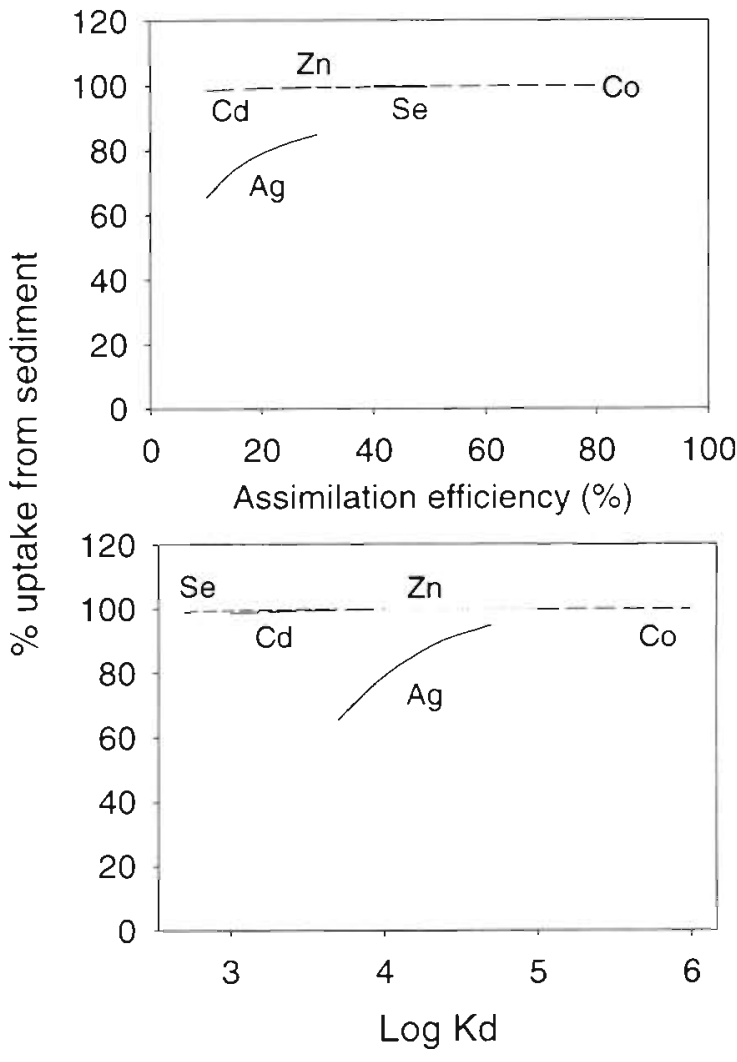

Fig. 9. Nereis succinea. Uptake from sediments of metals in $N$. succiena calculated by the kinetic model for different AEs and partition coefficients for sediments $\left(\mathrm{l} \mathrm{kg}^{-1}\right)\left(K_{\mathrm{d}}\right)$. Values are calculated percentages of total metal uptake obtained from sediment ingestion. For each metal, the chemical symbol is placed over its measured range of AE or $K_{d}$ values. To calculate the effects of variations in $\mathrm{AE}$ or $K_{d}$, mean numeric values of other parameters were used: for $\mathrm{Ag}, \mathrm{AE}=20 \%, K_{\mathrm{d}}=10^{4}$; for Cd, $\mathrm{AE}=20 \%, K_{\mathrm{d}}=2 \times 10^{3} ;$ for $\mathrm{Co}, \mathrm{AE}=65 \%, K_{\mathrm{d}}=2 \times 10^{5} ;$ for $\mathrm{Se}, \mathrm{AE}=40 \%, K_{\mathrm{d}}=10^{3} ;$ for $\mathrm{Zn}, \mathrm{AE}=35 \%, K_{\mathrm{d}}=2 \times 10^{4}$. The mean uptake rate constant $\left(k_{\mathrm{u}}\right)$ from the dissolved phase for each metal was from Fig. 8 , and the ingestion rate was assumed to be $3.5 \mathrm{~g} \mathrm{~g}^{-1}$ dry wt $\mathrm{d}^{-1}$

Our experiments also demonstrated that the exposure period of sediments to metals significantly affected $\mathrm{Cd}$ assimilation in polychaetes, but had no major effect on $\mathrm{Ag}, \mathrm{Co}, \mathrm{Se}$ and $\mathrm{Zn}$ assimilation. In bivalves, metal assimilation is greatly dependent on sediment exposure time; when sediments were radiolabeled for $6 \mathrm{mo}$, for example, AEs of $\mathrm{Cd}$, Co and $\mathrm{Ag}$ decrease 2- to 4-fold compared to 3 d labeling, implying that a greater proportion of the radioisotopes are refractory as sediment exposure periods increase (Griscom \& Fisher unpubl.). In our experiments, the kinetics of radiotracer binding with different geochemical fractions in the sediments was not measured. However, considerable desorption occurred for all metals, especially at $\mathrm{pH}$ 6, indicating that metals were primarily bound with easily exchanging pools of sediments. 
Measurements of metal AEs from sediment using radiotracers depend on the radiotracers being in equilibrium with the stable metals in the sediment. When the radioisotopes are not in equilibrium with the stable metal pools, the determined AEs may overestimate metal bioavailability from sediments. In the kinetic model, both metal AE and metal concentration in sediment affect metal influx into benthic animals from sediments (Eq. 1). To overcome the concern regarding equilibration between radioactive and stable metal, the measured AE should be coupled with metal concentration from the same geochemical fractions within the sediment (Luoma 1989). For example, model-predicted $\mathrm{Cr}$ concentrations in marine mussels were comparable to field measurements when the $\mathrm{Cr}$ AE measured by a radiotracer technique was coupled to $\mathrm{Cr}$ concentration in sediments determined by weak acid extraction (Wang et al. 1997). When the total Cr concentration (including $\mathrm{Cr}$ in the sediment matrix) was incorporated into the model, however, the predicted concentrations were much higher than the actual measurements. Presumably metals in the more refractory pool are unavailable to the animals during the rapid gut passage of sediment particles.

Whereas desorption from ingested sediments was correlated to assimilation for $\mathrm{Ag}, \mathrm{Cd}$ and $\mathrm{Co}$ in marine mussels (Gagnon \& Fisher 1997), we did not find any relationship between metal desorption and metal assimilation in Nereis succinea, suggesting that metal desorption was unlikely to control metal assimilation. One possible explanation is the longer gut passage time in $N$. succinea than in mussels $(3 \mathrm{~h})$; thus metal assimilation may become more dependent on the worm digestive physiology. Consequently, chemical extraction without consideration of an animal's digestive physiology may not be able to predict metal bioavailability from ingested sediments. Of course, our experimental approach did not exactly simulate the behavior of metals within the gut, as the radiolabeled sediments were resuspended in water and with a much lower sediment to water volume ratio than sediment to gut volume ratio. Mayer et al. (1996) quantified contaminant (including $\mathrm{Pb}$ and $\mathrm{Cu}$ ) desorption in 'gut juices' extracted from the marine deposit feeder Arenicola marina. The desorbed contaminant pools were considered to be potentially bioavailable to the organisms, because the contaminants ultimately assimilated by the organisms were presumed to be dissolved (although a few metals can also be taken up by pinocytosis, Simkiss \& Taylor 1989). Mayer et al. (1996) also showed that there was a linear relationship in metal extraction efficiency using 'gut juices' and direct desorption into seawater, but the latter extraction gave a much lower efficiency than 'gut juice' extraction.
Isotopic exchange between radiotracers and stable metals within the guts of deposit feeders may complicate the interpretation of experimental results using radioisotopes. Chen et al. (unpubl.) have recently determined that metal concentrations in the digestive fluids of Arenicola marina were several orders of magnitude higher than background seawater concentrations. If the kinetics of exchange is rapid (e.g. shorter than the gut passage time), some radioisotopes may exchange with metal pools in the gut, resulting in an overestimation of metal AE. Chen et al. (unpubl.) suggested that the metal levels in gut fluid did not result from the most recent sediment passage through the gut $_{i}$ thus it appeared that isotope exchange in the gut is slow.

\section{Metal uptake from the dissolved phase}

Assessments of metal influx in marine polychaetes can be overestimated by metal adsorption onto the body surface (reversible binding) or underestimated by metal efflux or decreased ventilating activity when the organisms are exposed for a prolonged time. In this study, we accounted for these interferences by subtracting the possible surface adsorption and only considering metal uptake within the first $11 \mathrm{~h}$ of metal exposure. With this approach, influx rates measured at 2, 6 and $10.5 \mathrm{~h}$ of exposure for each individual worm are nearly identical. The applicability of uptake rates measured during short exposure periods to natural environments in which the worms are chronically exposed was not assessed.

In marine mussels, the power coefficients describing the relationship between the log of influx rate and the $\log$ of metal concentration in the dissolved phase are about 1 (Wang et al. 1996). This trend was also observed for $\mathrm{Ag}, \mathrm{Co}$, Se (present study) and $\mathrm{Hg}$ (Wang et al. 1998) in Nereis succinea. In contrast, the power values for $\mathrm{CH}_{3} \mathrm{Hg}$ in worms are 1.33 (Luoma 1977, Wang et al. 1998), indicating that the rates of metal uptake increased disproportionately with increasing methylmercury concentrations. The lower power coefficients (0.6 to 0.7 ) for $\mathrm{Cd}$ and $\mathrm{Zn}$ suggest that these metals are regulated during their uptake from the dissolved phase. Regulation of $\mathrm{Zn}$ uptake in marine polychaetes has been previously documented, primarily because the worms developed an efficient efflux system to remove excess metal (Bryan \& Hummerstone 1973). In marine mussels, there is no indication that $\mathrm{Zn}$ uptake from the dissolved phase is regulated (Wang et al. 1996) but uptake of $\mathrm{Zn}$ from food does appear to be regulated (Wang \& Fisher 1996).

The weight-specific uptake rates of $\mathrm{Cd}, \mathrm{Co}$, Se and $\mathrm{Zn}$ in Nereis succinea are at least an order of magni- 
tude lower than in mussels and copepods (Wang et al. 1996, Wang \& Fisher 1998). As with mussels and copepods, metals ( $\mathrm{Ag}, \mathrm{Zn}$ and $\mathrm{Cd}$ ) that tend to associate with proteins display a higher dissolved uptake rate than other elements. Among the metals examined, $\mathrm{CH}_{3} \mathrm{Hg}$ exhibits the highest uptake rate from the dissolved phase (Wang et al. 1998), probably because it can pass freely through membranes (Mason et al. 1996).

\section{Modeling the pathways of metal uptake}

Our calculation demonstrates that most metals considered in this study ( $\mathrm{Cd}, \mathrm{Co}$, Se and $\mathrm{Zn}$ ) are accumulated by Nereis succinea by ingestion of sediments, regardless of variations in IR, AE and $K_{\mathrm{d}}$ values. For $\mathrm{Ag}$, which has the highest uptake rate from the dissolved phase, the relative importance of dissolved uptake and sediment ingestion depends more heavily on its AE and $K_{d}$, but uptake from the dissolved phase contributes only 5 to $35 \%$ of total Ag accumulation in the worm. Similarly, in $N$. diversicolor, both dissolved and sediment-bound Ag have been shown to contribute to Ag accumulation (Bryan \& Langston 1992). The dominance of metal uptake from ingested sediments is mainly due to the high feeding rate of the worms and the low uptake rate from the dissolved phase. Many deposit feeders are able to ingest sediments at least twice their tissue dry weight each day (Cammen 1980b); thus the potential of sediment as a major source for metal uptake is high. In addition, $N$. succinea is a facultative deposit feeder ingesting primarily surface oxic sediment. The higher AEs associated with these sediments may also contribute partially to the dominance of sediment as a source for metals in these worms.

Recently, we employed this kinetic model to separate the relative importance of solute and sediment pathways for $\mathrm{Hg}(\mathrm{II})$ and $\mathrm{CH}_{3} \mathrm{Hg}$ (II) accumulation in Nereis succinea (Wang et al. 1998). Our model showed that $\mathrm{CH}_{3} \mathrm{Hg}$ (II) contributes about 5 to $17 \%$ of the total $\mathrm{Hg}$ accumulation in the polychaetes, and that most (>70\%) of the $\mathrm{Hg}(\mathrm{II})$ accumulation is from sediment ingestion, whereas for $\mathrm{CH}_{3} \mathrm{Hg}(\mathrm{II})$ the relative importance of dissolved uptake and sediment ingestion depends greatly on its $K_{\mathrm{d}}$ in sediment. Thus sediment can also constitute an important source for the overall accumulation of $\mathrm{Hg}$ in worms.

This kinetic model has also been used to evaluate the sources of metal uptake in marine mussels and copepods (Wang \& Fisher 1997, 1998). Both food and solute uptake can contribute to metal accumulation in these animals. In mussels, $\mathrm{Cd}$ is accumulated predominantly from the dissolved phase whereas for other metals the ingestion of food is a more important source for metal accumulation. In copepods, solute uptake dominates $\mathrm{Ag}, \mathrm{Cd}$ and Co accumulation, whereas food uptake dominates $\mathrm{Zn}$ accumulation. Se is the only element which has been consistently shown to be predominantly accumulated from food in a variety of marine invertebrates (Luoma et al. 1992, Wang et al. 1996, Wang \& Fisher 1998). Consequently, the importance of different uptake pathways is highly dependent on the biology of each species and the geochemistry of metals in the environment.

Very few experimental studies have quantified the relative importance of sediment and solute uptake in marine deposit feeders. Kemp \& Swartz (1988) indicated that porewater was the dominant route for $\mathrm{Cd}$ uptake in amphipods. However, Luoma \& Fisher (1997) noted that in that study the porewater Cd concentration was enhanced by 1000 to $10000 \times$ over the concentration found in contaminated estuarine waters, whereas concentrations in food were only enhanced by 16 to $72 \times$ compared to moderately contaminated sediments. Cd was therefore not in true equilibrium between porewater and sediments. Using environmentally realistic $\mathrm{Cd}$ partitioning in porewater and sediments, Luoma \& Fisher (1997) instead calculated that $91 \%$ of $\mathrm{Cd}$ can arise from ingestion of sediments. Selck et al. (1998) compared Cd uptake in the polychaete Capitella sp. exposed to dissolved $\mathrm{Cd}$ (water only treatment), sediment-bound Cd (sediment-bound only treatment) and both dissolved and sediment-bound $\mathrm{Cd}$ (porewater + sediment treatment). They calculated that sediment-bound $\mathrm{Cd}$ contributed $95 \%$ of the total Cd taken up by the worms.

Separation of the pathways of metal uptake in marine benthic organisms is important for the setting of appropriate sediment quality criteria. Currently, one set of proposed sediment quality criteria is based on the assumptions that sediment AVS controls metal porewater concentrations and that metal toxicity results only from uptake from porewater (Ankley et al. 1996). Sediment was considered to be in equilibrium with porewater and to indirectly affect metal accumulation due to the controls of AVS on porewater metal concentration. Our study demonstrates that sediment quality criteria based on porewater toxicity tests would not protect deposit feeders such as Nereis succinea. We believe it is necessary to conduct additional mechanistic studies using environmentally realistic metal concentrations to better evaluate the importance of different uptake pathways for benthic invertebrates. Clearly, the high ingestion rate of deposit feeders and their slow metal uptake from the dissolved phase should be taken into consideration. 
The kinetic modeling approach can overcome many of the experimental limitations in quantifying uptake pathways of metals. In the model, uptake from both dissolved and food sources are separately measured, and the variability of each parameter can be controlled and quantified. The model can consider metal accumulation under the diverse environmental conditions the animals are likely to encounter in the field. In our calculations, the most variable and least certain parameter is the metal $K_{\mathrm{d}}$, which is dependent on many geochemical processes (e.g. redox conditions, binding with different geochemical fractions in the sediments, organic carbon content, etc.; Tessier 1992).

There are very few field measurements available to validate the kinetic model developed for Nereis succinea in the present study, and a field study to specifically test the validity of the AE measurements and the kinetic model in these worms is warranted. In a companion study on $\mathrm{Hg}$ bioavailability to $N$. succinea, Wang et al. (1998) calculated that, using $\mathrm{Hg}$ and methyl Hg AEs determined experimentally by methods employed here, the kinetic model predicts $\mathrm{Hg}$ concentrations in the worms in the range of 0.05 to $0.5 \mu \mathrm{g}$ $\mathrm{g}^{-1}$, which were within the range of field measured $\mathrm{Hg}$ concentrations (0.02 to $0.1 \mathrm{\mu g} \mathrm{g}^{-1}$, Luoma 1977$)$.

In summary, our results suggest that trace metal assimilation from ingested sediment in the polychaete Nereis succinea was little affected by sediment organic carbon and particle grain size. Metals associated with anoxic sediments were less assimilated by the worms than metal in oxic sediments (except for Se). Further studies are required to elucidate the mechanisms underlying the biological and geochemical controls of metal assimilation from sediments. Dissolved uptake of metals was directly proportional to metal concentration in the dissolved phase, but $\mathrm{Cd}$ and $\mathrm{Zn}$ appeared to be regulated during their uptake by the worms. A kinetic model calculation indicates that most (>98\%) $\mathrm{Cd}, \mathrm{Co}$, Se and $\mathrm{Zn}$ bioaccumulation is from ingestion of sediments, primarily due to the very high ingestion rates of the worms and their slow uptake from the dissolved phase. Our work therefore suggests that the establishment of sediment quality criteria must consider sediments as a potentially important source for metal uptake in benthic invertebrates and that feeding behavior and digestive physiology need to be considered in studies examining metal bioaccumulation from contaminated sediments.

Acknowledgements. We thank 2 anonymous reviewers for many constructive comments on this paper This research was supported by a grant from the Hudson River Foundation to N.S.F. W.X.W. acknowledges the support of the Hong Kong University of Science and Technology during the writing of this paper This is MSRC Contribution No. 1104.

\section{LITERATURE CITED}

Ankley GT (1996) Evaluation of metal/acid-volatile sulfide relationships in the prediction of metal bioaccumulation by benthic macroinvertebrates. Environ Toxicol Chem 15: $2138-2146$

Ankley GT, Di Toro DM, Hansen DJ, Berry WJ (1996) Technical basis and proposal for deriving sediment quality criteria for metals. Environ Toxicol Chem 15:2056-2066

Bergman HL, Dorward-King EJ (eds) (1997) Reassessment of metals: criteria for aquatic life protection. SETAC Press, Pensacola, FL

Bryan GW, Hummerstone LG (1973) Adaptation of the polychaete Nereis diversicolor to estuarine sediments containing high concentrations of zinc and cadmium. J Mar Biol Assoc UK 53:839-857

Bryan GW, Langston WJ (1992) Bioavailability, accumulation and effects of heavy metals in sediments with special reference to United Kingdom estuaries: a review. Environ Pollut 76:89-131

Cammen LM (1980a) A method for measuring ingestion rate of deposit feeders and its use with the polychaete Nereis succinea. Estuaries 3:55-60

Cammen LM (1980b) Ingestion rate: an empirical model for aquatic deposit feeders and detritivores. Oecologia 44 303-310

Campbell PGC, Tessier A (1997) Ecotoxicology of metals in the aquatic environment: geochemical aspects. In: Newman $\mathrm{MC}$, Jagoe $\mathrm{CH}$ (eds) Ecotoxicology: a hierarchical treatment. CRC, Boca Raton, FL, p 11-58

Campbell PGC, Lewis AG, Chapman PM, Crowder AA, Fletcher WK, Imber B, Luoma SN, Stokes PM, Winfrey $M$ (1988) Biologically available metals in sediments. Publication No. NRCC 27694, National Research Council of Canada, Ottawa

Decho AW, Luoma SN (1994) Humic and fulvic acids: sink or source in the availability of metals to the marine bivalves Macoma balthica and Potamocorbula amurensis? Mar Ecol Prog Ser 108:133-145

Di Toro DM, Mahony JD, Hansen DJ, Scott KJ, Carlson AR (1993) Acid volatile sulfide predicts the acute toxicity of cadmium and nickel in sediments. Environ Sci Technol 26: 96-101

Fisher NS, Teyssié JL, Fowler SW, Wang WX (1996) Accumulation and retention of metals in mussels from food and water: a comparison under field and laboratory conditions. Environ Sci Technol 30:3232-3242

Forbes VE, Forbes TL (1997) Dietary absorption of sedimentbound fluoranthene by a deposit-feeding gastropod using the ${ }^{14} \mathrm{C}:{ }^{51} \mathrm{Cr}$ dual-labeling method. Environ Toxicol Chem 16:1002-1009

Gagnon C, Fisher NS (1997) The bioavailability of sedimentbound $\mathrm{Cd}, \mathrm{Co}$ and Ag to the mussel, Mytilus edulis. Can J Fish Aquat Sci 54:147-156

Harvey RW, Luoma SN (1985) Effect of adherent bacteria and bacterial extracellular polymers upon assimilation by Macoma balthica of sediment-bound $\mathrm{Cd}, \mathrm{Zn}$ and $\mathrm{Ag}$. Mar Ecol Prog Ser 22:281-289

IAEA (Internaional Atomic Energy Agency) (1985) Sediment $\mathrm{Kds}$ and concentration factors for radionuclides in the marine environments. IAEA, Vienna

Ingersoll CG, Dillon T, Biddinger GR (eds) (1997) Ecological risk assessment of contaminated sediments. SETAC Press, Pensacola, FL

Kemp PF, Swartz RC (1988) Acute toxicity of interstitial and particle-bound cadmium to a marine infaunal amphipod. Mar Environ Res 26:135-153 
Kukkonen J, Landrum PF (1995) Measuring assimilation efficiencies for sediment-bound PA.H and PCB congeners by benthic organisms. Aquat Toxicol 32:75-92

Lopez GR, Levinton JS (1987) Ecology of deposit-feeding animals in marine sediments. Q Rev Biol 62:235-260

Luoma SN (1977) Dynamics of biologically available mercury in a small estuary. Estuar Coast Mar Sci 5:643-652

Luoma SN (1989) Can we determine the biological availability of sediment-bound trace elements? Hydrobiologia 176/177:379-401.

Luoma SN, Bryan GW (1982) A statistical study of environmental factors controlling concentrations of heavy metals in the burrowing bivalve Scrobicularia plana and the polychaete Nereis diversicolor. Estuar Coast Shelf Sci 15:95-108

Luoma SN, Fisher NS (1997) Uncertainties in assessing contaminant exposure from sediments. In: Ingersoll CG, Dillon T, Biddinger GR (eds) Ecological risk assessment of contaminated sediments. SETAC, Pensacola, FL, p 211-237

Luoma SN, Jenne EA (1977) The availability of sedimentbound cobalt, silver and zinc to a deposit-feeding clam. In: Wildung RW, Drucker $\mathrm{H}$ (eds) Biological implications of metals in the environment. ERDA Conf. 750920, National Technical Information Service, Springfield, VA, p 213-230

Luoma SN, Johns C, Fisher NS, Steinberg NS, Oremland RS, Reinfelder JR (1992) Determination of selenium bioavailability to a benthic bivalve from particulate and solute pathways. Environ Sci Technol 26:485-491

Lydy MJ, Landrum PF (1993) Assimilation efficiency for sediment-sorbed benzo(a)pyrene by Diporeia spp. Aquat Toxicol 26:209-224

Mason RP, Reinfelder JR, Morel FMM (1996) Uptake, toxicity, and trophic transfer of mercury in a coastal diatom. Environ Sci Technol 30:1835-1845

Mayer LM, Chen Z, Findlay RH, Fang J, Sampson J, Self RL, Jumars PA, Quetel C, Donard OF (1996) Bioavailability of sedimentary contaminants subject to deposit-feeder digestion. Environ Sci Technol 30:2641-2645

Reinfelder JR, Wang WX, Luoma SN, Fisher NS (1997) Assimilation efficiencies and turnover rates of trace elements in

Editorial responsibility: Otto Kinne (Editor),

Oldendorf/Luhe, Germany marine bivalves: a comparison of oysters, clams, and mussels. Mar Biol 129:434-452

Selck H, Forbes VE, Forbes TL (1998) Toxicity and toxicokinetics of cadmium in Capitella sp. 1: relative importance of water and sediment as routes of cadmium uptake. Mar Ecol Prog Ser 164:167-178

Simkiss K, Taylor MG (1989) Metal fluxes across the membranes of aquatic organisms. Rev Aquat Sci 1:172-188

Tessier A (1992) Sorption of trace elements on natural particles in oxic environments. In: Buffle $\mathrm{J}$, Van Leeuwen HP (eds) Environmental particles: environmental, analytical and physical chemistry series. Lewis, Boca Raton, FL, p $425-453$

Thomann RV (1981) Equilibrium model of fate of microcontaminants in diverse aquatic food chains. Can J Fish Aquat Sci 38:280-296

Thomann RV, Mahony JD, Mueller R (1995) Steady-state model of biota sediment accumulation factor for metals in two marine bivalves. Environ Toxicol Chem 14:1989-1998

Wallace WG, Lopez GR (1997) Bioavailability of biologically sequestered cadmium and the implications of metal detoxification. Mar Ecol Prog Ser 147:149-157

Wang WX, Fisher NS (1996) Assimilation of trace elements by the mussel Mytilus edulis: effects of diatom chemical composition. Mar Biol 125:715-724

Wang WX, Fisher NS (1997) Modeling metal bioavailability for marine mussels. Rev Environ Contam Toxicol 151: $39-65$

Wang WX, Fisher NS (1998) Accumulation of trace elements in a marine copepod. Limnol Oceanogr 43:273-283

Wang WX, Fisher NS, Luoma SN (1996) Kinetic determinations of trace element bioaccumulation in the mussels Mytilus edulis. Mar Ecol Prog Ser 140:91-113

Wang WX, Griscom SB, Fisher NS (1997) Bioavailability of Cr(III) and Cr(VI) to marine mussels from solute and particulate pathways. Environ Sci Technol 31:603-611

Wang WX, Stupakoff I, Gagnon C, Fisher NS (1998) Bioavailability of inorganic and methylmercury to a marine depositfeeding polychaete. Environ Sci Technol 32:2564-2571

Submitted: March 23, 1998; Accepted: November 6, 1998

Proofs received from author(s): March 2, 1999 